\title{
Synthesis and conformational properties of 1,3-dimethyl-3-phenyl- 1,3-azasilinane. Low temperature dynamic NMR and computational study
}

\author{
Bagrat A. Shainyan, ${ }^{\mathrm{a}}$ Svetlana V. Kirpichenko, ${ }^{\mathrm{a}}$ and Erich Kleinpeter ${ }^{\mathrm{b}} *$ \\ ${ }^{a}$ A. E. Favorsky Irkutsk Institute of Chemistry, Siberian Division of the Russian Academy of \\ Science, 1 Favorsky Street, 664 033, Irkutsk, Russian Federation \\ ${ }^{b}$ Chemisches Institut der Universität Potsdam, Karl-Liebknecht-Str. 24-25, D-14476 Potsdam \\ (Golm), Germany \\ E-mail: ekleinp@uni-potsdam.de, bagrat@irioch.irk.ru
}

Dedicated to Professor Ferenc Fülöp on the occasion of his $60^{\text {th }}$ birthday

\begin{abstract}
1,3-Dimethyl-3-phenyl-1,3-azasilinane was synthesized and its conformational behavior was studied by the low temperature NMR spectroscopy and quantum chemical calculations. The compound was shown to exist as an equilibrium mixture of the $\mathrm{Ph}_{\mathrm{ax}} \mathrm{Me}_{\mathrm{eq}}$ and $\mathrm{Ph}_{\mathrm{eq}} \mathrm{Me}_{\mathrm{ax}}$ chair conformers with the N-methyl substituent in equatorial position. The barrier to ring inversion was also determined.
\end{abstract}

Keywords: 1,3-Dimethyl-3-phenyl-1,3-azasilinane, conformational analysis, low temperature NMR spectroscopy, quantum chemical calculations

\section{Introduction}

Azasilinanes, and in particular 1,4-azasilinanes, are the most studied heterocyclic organosilicon compounds. ${ }^{1}$ This is mainly due to the fact that they are analogs of known drugs possessing specific pharmacological properties. ${ }^{2-8}$ Effective methods for their preparation as well as X-ray investigation of their molecular structure have been reported. ${ }^{3-8}$ Recently, a renewal of interest in 1,3-azasilinanes has occurred as potential biologically active compounds. ${ }^{9,10}$ A distinctive feature of bioactive 1,3- and 1,4-azasilinanes is the presence of aryl at silicon and that the biological activity proved to be dependent on the axial or equatorial orientation of the aryl group. The stereochemistry of the carbon analogs, geminally disubstituted 3-Me-3-Ph-piperidines has been studied by ${ }^{1} \mathrm{H}$ and ${ }^{13} \mathrm{C}$ NMR spectroscopy, although only at room temperature. ${ }^{11}$ 
Cyclic organosilicon compounds having a $\mathrm{Ph}-\mathrm{Si}$ bond are of general interest from both synthetic and theoretical point of view. Cleavage of this bond with electrophilic agents provides the possibility for preparing the corresponding sila-functionalized heterocycles such as silacyclohexanes, ${ }^{1,12}$ 1,3-thiasilinanes ${ }^{12}$ and e.g. 1,3 -azasilinanes. ${ }^{10}$ We also prepared 3-X-3-Me1,3-thiasilinanes $(\mathrm{X}=\mathrm{H}, \mathrm{F})$ from 3-Me-3-Ph-1,3-thiasilinanes ${ }^{12}$ in order to study the conformational behavior of the latter thiasilinanes ${ }^{13,14}$ as well as of 3-Me-3-Ph-1,3-thiasilinane itself. $^{14}$

It is a general rule that monosubstituted cyclohexanes prefer the equatorial conformation because of unfavorable 1,3-diaxial interactions in the axial conformation. ${ }^{15}$ In the certain case of geminally disubstituted cyclohexanes, the substituent of the larger conformational energy (A value) shows a greater preference for the equatorial position. However, even the simplest representative of this class of compounds, 1-methyl-1-phenylcyclohexane, exhibits an exception from this rule: ${ }^{16,17}$ the $\mathrm{Me}_{\mathrm{eq}} \mathrm{Ph}_{\mathrm{ax}}$ conformer is $0.32 \mathrm{kcal} \mathrm{mol}{ }^{-1}$ more stable than the $\mathrm{Me}_{\mathrm{ax}} \mathrm{Ph}_{\mathrm{eq}}$ conformer in spite of the larger conformational energy of the phenyl group $\left(2.87 \mathrm{kcal} \mathrm{mol}^{-1}\right)^{15}$ as compared to the methyl group $\left(1.80 \mathrm{kcal} \mathrm{mol}^{-1}\right)^{15}$ and the stability of the $\mathrm{Me}_{\mathrm{eq}} \mathrm{Ph}_{\mathrm{ax}}$ and $\mathrm{Me}_{\mathrm{ax}} \mathrm{Ph}_{\mathrm{eq}}$ conformers is reversed again in favor of the latter when the two substituents are attached to silicon, rather than to carbon, as we have exemplified for 1-methyl-1-phenyl-1-silacyclohexane and 3-methyl-3-phenyl-3-thiasilinane. ${ }^{14}$

In continuation of our systematic studies of the effect of heteroatoms on the conformational preferences of the geminally $\mathrm{Si}-\mathrm{Me}, \mathrm{Ph}$ substituted six-membered heterocycles we report in this paper the synthesis of 1,3-dimethyl-3-phenyl-1,3-azasilinane $\mathbf{1}$ and the elucidation of its conformational behavior by low-temperature NMR spectroscopy and quantum chemical calculations.

\section{Results and Discussion}

1,3-Dimethyl-3-phenyl-1,3-azasilinane $\mathbf{1}$ was synthesized starting from (chloromethyl)methyldichlorosilane $\mathbf{2}$ (Scheme 1). The treatment of $\mathbf{2}$ with $\mathrm{PhMgBr}$ gave (chloromethyl)methylphenylchlorosilane 3 (50\% yield), which upon the reaction with $\mathrm{LiAlH}_{4}$ afforded the corresponding hydrosilane 4 (75\% yield). Reaction of 4 with allyl chloride in the presence of Speier's catalyst resulted in the corresponding adduct 5 (11\% yield), which by sequential treatment with $\mathrm{MeNH}_{2}$ in benzene solution finally afforded the title compound $\mathbf{1}$ (57\% yield). 

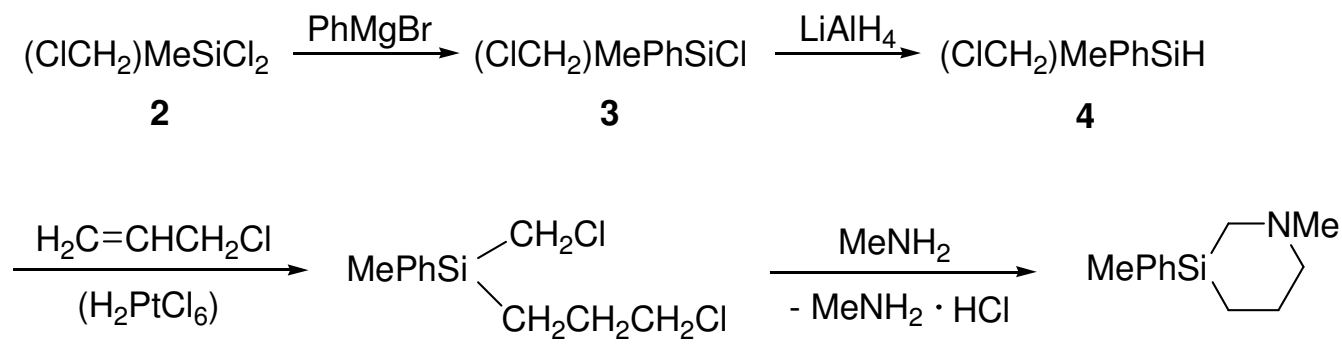

5

1

\section{Scheme 1}

In the room temperature ${ }^{13} \mathrm{C}$ NMR spectrum each carbon atom is represented by a single line. Due to the presence of the chiral silicon center in the molecule, protons of methylene groups are diastereotopic: at $273 \mathrm{~K}$, the $4-\mathrm{CH}^{A}$ and $4-\mathrm{CH}^{B}$ resonate separately at 0.85 and $1.00 \mathrm{ppm}$ as multiplets of 8 lines each, the 5- $\mathrm{CH}_{2}$ group exhibiting a very complex multiplet at about 2.00 ppm, the 2- $\mathrm{CH}_{2}$ group proves to be an $\mathrm{AB}$ system at 2.10 and $2.15 \mathrm{ppm}$, respectively, and the 6$\mathrm{CH}^{A}$ and $6-\mathrm{CH}^{B}$ protons also resonate separately at 2.4 and $2.5 \mathrm{ppm}$ as multiplets, the former overlapped with the NMe singlet. With lowering the temperature, all proton signals are broadened and split finally indicating that compound $\mathbf{1}$ exists as an equilibrium mixture of two conformers shown in Scheme 2. The dynamic ${ }^{1} \mathrm{H}$ NMR study is given in Figure 1, the resolved ${ }^{1} \mathrm{H}$ NMR spectrum with assignment of the signals is shown in Figure 2, the ${ }^{1} \mathrm{H}$ and ${ }^{13} \mathrm{C}$ signals of the aliphatic part are given in Table 1; aromatic ${ }^{1} \mathrm{H}$ and ${ }^{13} \mathrm{C}$ parts of the spectra are congruent.

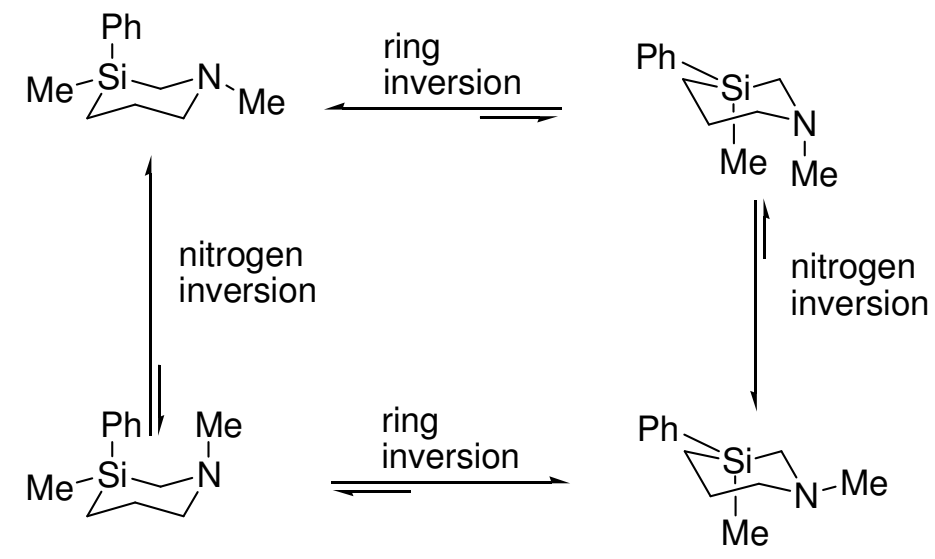

\section{Scheme 2}




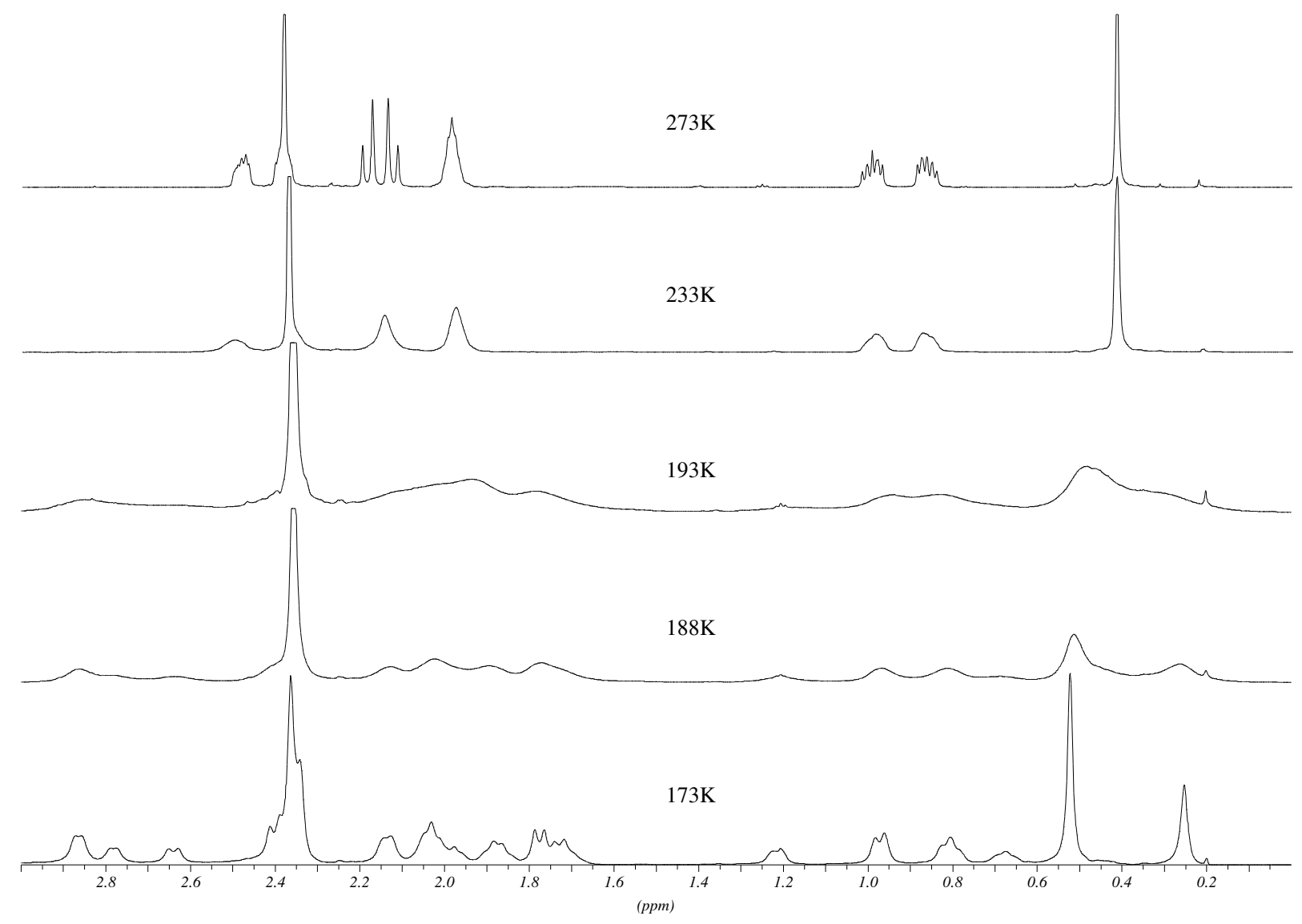

Figure 1. Variable temperature ${ }^{1} \mathrm{H}$ NMR spectra of 1,3-dimethyl-3-phenyl-1,3-azasilinane $\mathbf{1}$.

Table 1. ${ }^{1} \mathrm{H}$ and ${ }^{13} \mathrm{C} \mathrm{NMR}$ data for compound 1 in $\mathrm{CD}_{2} \mathrm{Cl}_{2} / \mathrm{CHCl}_{2} \mathrm{~F} / \mathrm{CHClF}_{2}$

\begin{tabular}{|c|c|c|c|c|c|c|c|}
\hline \multicolumn{2}{|c|}{$\mathrm{T} / \mathrm{K}$, conform. $\mathrm{Si}-\mathrm{Me}$} & $\mathrm{MeSi}$ & $2-\mathrm{CH}_{2}$ & $4-\mathrm{CH}_{2}$ & $5-\mathrm{CH}_{2}$ & $6-\mathrm{CH}_{2}$ & $\mathrm{NMe}$ \\
\hline & & \multicolumn{6}{|c|}{$\delta\left({ }^{1} \mathrm{H}\right) / \mathrm{ppm}$} \\
\hline \multirow[t]{2}{*}{273} & & 0.42 & 2.15 & 0.86 & 1.99 & 2.38 & 2.38 \\
\hline & & & & 0.99 & & 2.48 & \\
\hline $173, \mathbf{1 b}$ & $a x$ & 0.52 & 1.77 & 0.81 & 1.88 & 2.03 & \\
\hline major & $e q$ & & 2.40 & 0.97 & 2.13 & 2.86 & 2.36 \\
\hline $173, \mathbf{1 a}$ & $a x$ & & 1.73 & 0.67 & $\sim 1.70$ & $\sim 1.98$ & \\
\hline \multirow[t]{2}{*}{ minor } & $e q$ & 0.25 & 2.64 & 1.21 & $\sim 1.98$ & 2.78 & 2.34 \\
\hline & & \multicolumn{6}{|c|}{$\delta\left({ }^{13} \mathrm{C}\right) / \mathrm{ppm}$} \\
\hline 273 & & -4.78 & 48.53 & 10.71 & 25.20 & 60.38 & 52.67 \\
\hline $173, \mathbf{1 b}$ & $a x$ & -7.07 & 47.38 & 9.58 & 24.09 & 59.22 & 51.85 \\
\hline \multicolumn{8}{|l|}{ major } \\
\hline $\begin{array}{c}173, \mathbf{1 a} \\
\text { minor }\end{array}$ & $e q$ & -3.75 & 46.94 & 9.09 & 24.32 & 59.16 & 51.98 \\
\hline
\end{tabular}




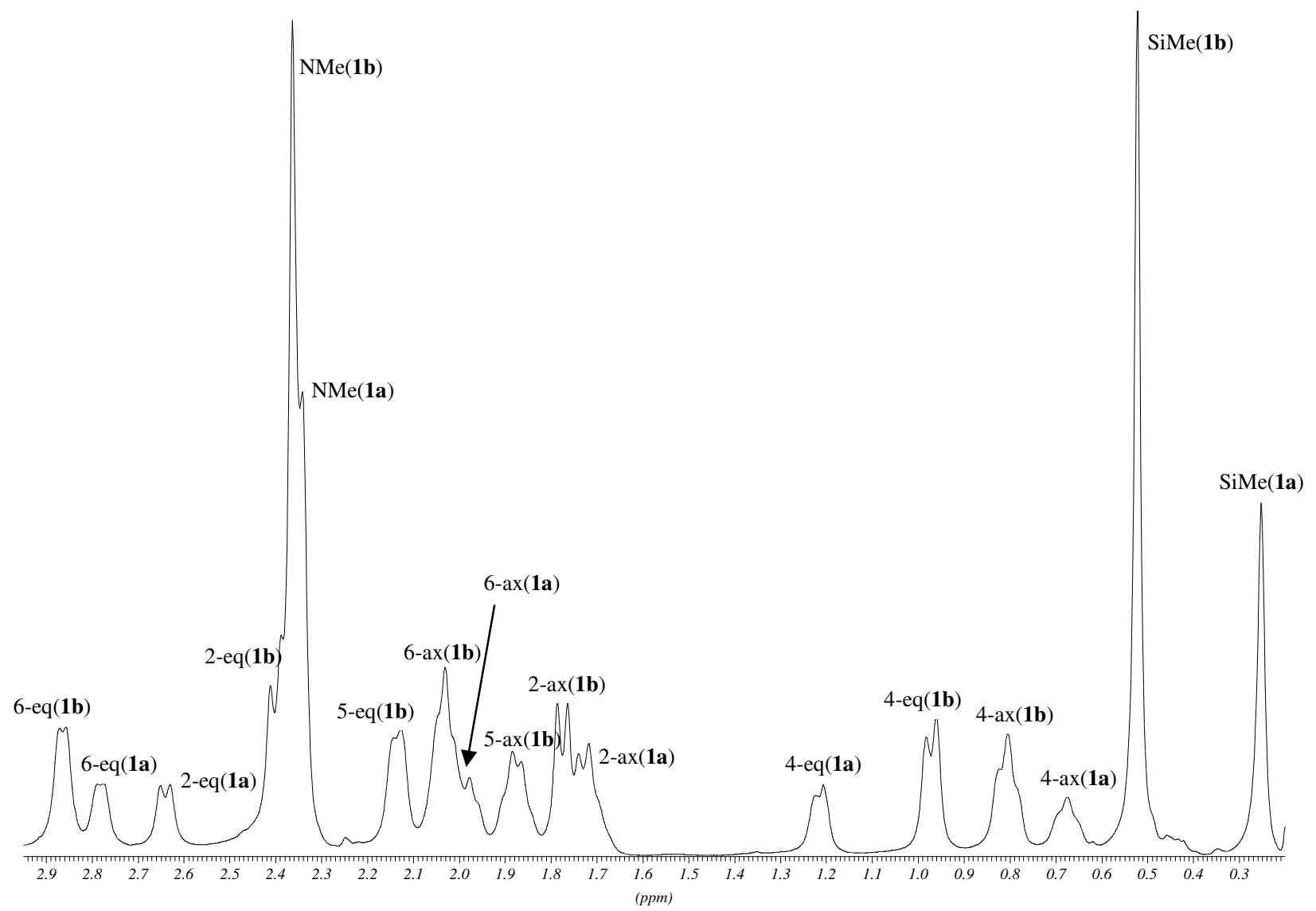

Figure 2. ${ }^{1} \mathrm{H}$ NMR spectrum of the frozen conformational equilibrium of 1,3-dimethyl-3-phenyl1,3-azasilinane $\mathbf{1}$ at $173 \mathrm{~K}$.

The assignment of signals in the frozen ${ }^{1} \mathrm{H}$ NMR spectrum (Figure 2) was made taking into account the splitting [axial protons with two (at C4 and C-6) or three large couplings (at C5), $\left.{ }^{3} \mathrm{~J}(\mathrm{gem}),{ }^{3} \mathrm{~J}(\mathrm{ax}, \mathrm{ax})\right]$ and the integral intensities of the signals, and using the HMQC and HMBC 2D NMR spectra at $143 \mathrm{~K}$. The ratio of the conformers is ca. 2:1. The assignment of the proton and carbon signals to the two preferred conformers $\mathbf{1 a}$ and $\mathbf{1 b}$ (Figure 2, Table 1) is in agreement with criteria established for 1-methyl-1-phenylcyclohexane, ${ }^{16}$ 3,5- and 3,6-dimethyl substituted 3-arylpiperidines: ${ }^{11}$ (i) equatorial $\mathrm{H}-2$ and $\mathrm{H}-4$ are deshielded in the $\mathrm{Me}_{\mathrm{eq}} \mathrm{Ph}_{\mathrm{ax}}$ conformer $\mathbf{1 a}$ as compared to those in the $\mathrm{Me}_{\mathrm{ax}} \mathrm{Ph}_{\mathrm{eq}}$ conformer 1b; (ii) axial $\mathrm{H}-2$ and $\mathrm{H}-4$ are shielded in 1a as compared to $\mathbf{1 b}$; (iii) axial 3-Me protons are deshielded by the nitrogen lone pair in $\mathbf{1 b}$ as compared to 1a; (iv) the axial SiMe carbon atom in $\mathbf{1 b}$ must resonate at higher field than the equatorial analog in 1a. Applying these criteria, the frozen spectra in Figure 2 allow us to conclude that $\mathbf{1 a}\left(3-\mathrm{Me}_{\mathrm{eq}}-3-\mathrm{Ph}_{\mathrm{ax}}\right)$ is the minor conformer and $\mathbf{1 b}\left(3-\mathrm{Me}_{\mathrm{ax}}-3-\mathrm{Ph}_{\mathrm{eq}}\right)$ is the major conformer. This assignment was unequivocally proved by the 2D HMBC NMR spectrum: the methyl carbon atom of the major conformer exhibits cross peaks to $\mathrm{C}(2,4)-\mathrm{H}(a x)$ while the phenyl ipso carbon atom of the minor conformers exhibit the corresponding cross peaks to $\mathrm{C}(2,4)-\mathrm{H}(a x)$ only; cross peaks between SiMe carbon and $\mathrm{C}_{i p s o}$ to $\mathrm{H}(2,4) e q$ protons, respectively, 
are not present due to the dihedral angle dependence of the vicinal ${ }^{3} \mathrm{~J}(\mathrm{C}, \mathrm{H})$ coupling as origin for the cross peaks.

A lower stability of the $3-\mathrm{Me}_{\mathrm{eq}}-3-\mathrm{Ph}_{\mathrm{ax}}$ conformer $\mathbf{1 a}$ is consistent with the same order of stability earlier found by us for 1-methyl-1-phenyl-1-silacyclohexane and 3-methyl-3-phenyl1,3-thiasilinane ${ }^{14}$ and with the larger conformational energy of the phenyl group. This order of stability is different from that for 1-methyl-1-phenylcyclohexane, ${ }^{17}$ the reasons were analyzed in detail previously. ${ }^{14}$ Possible explanation of the lower stability of $\mathbf{1 a}$ vs. 1b comes from consideration of the optimized structure of the molecule (Figure 3).

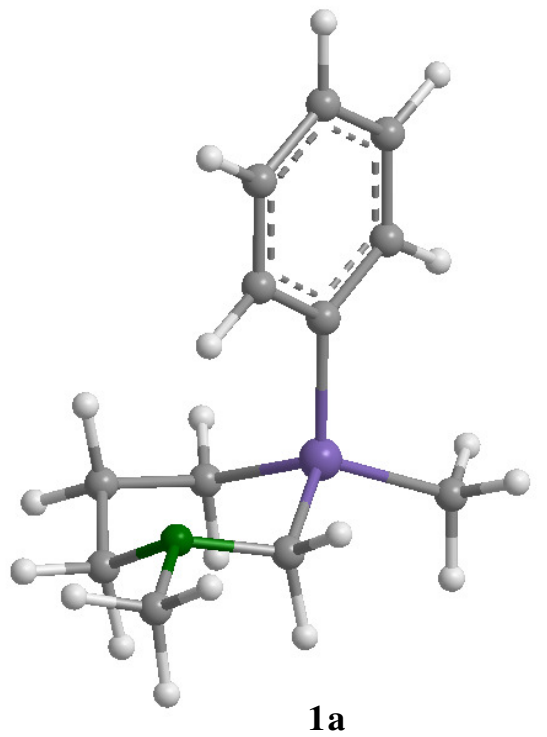

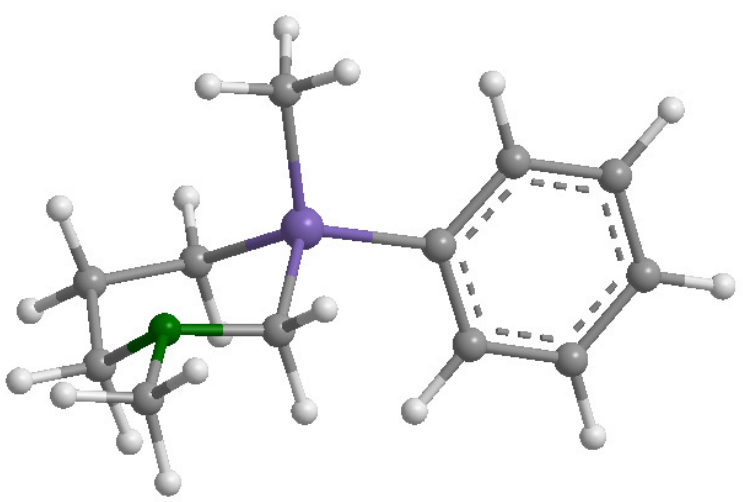

$1 \mathbf{b}$

Figure 3. Optimized structure of conformers $\mathbf{1 a}$ and $\mathbf{1 b .}$

In conformer $\mathbf{1 b}$ the plane of the equatorial phenyl group is perpendicular to the mean plane N1-C2-C4-C6 of the 1,3-azasilinane ring system, whereas in conformer 1a the plane of the axial phenyl group is turned about the $\mathrm{Si}-\mathrm{C}_{i p s o}$ bond in such a way that one of the ortho-protons is oriented directly to the lone pair of the nitrogen atom. This results in a reduced contact $\mathrm{N} \cdots \mathrm{H}_{\text {ortho }}$ of $2.49 \AA$, which is $0.21 \AA$ shorter than the sum of the van der Waals radii $(2.7 \AA)$ and provides an additional steric destabilization of $\mathbf{1 a}$ as confirmed by some shortening of the interacting $\mathrm{C}-\mathrm{H}_{\text {ortho }}$ bond as compared to the corresponding noninteracting $\mathrm{C}-\mathrm{H}_{\text {ortho }}$ bond.

The presence of only one NMe signal for each conformer is indicative of the fact that the nitrogen inversion is still fast on the NMR time scale at the temperature of our measurements.

The ratio of the conformers $1 \mathbf{a}: \mathbf{1 b}$ of $1: 2$ in the frozen equilibrium corresponds to a free energy difference $\Delta \mathrm{G}^{\mathrm{o}}=0.24 \mathrm{kcal} \mathrm{mol}^{-1}$.

The barrier to ring inversion $\Delta \mathrm{G}^{\neq}$of $9.0 \mathrm{kcal} \mathrm{mol}^{-1}$ was calculated from decoalescence of the SiMe protons, SiMe carbons and C-2, C-4 and C-5 signals, as shown in Table 2. 
Table 2. Dynamic NMR parameters and barrier to ring inversion of 1,3-dimethyl-3-phenyl-1,3azasilinane 1

\begin{tabular}{ccccc}
\hline $\begin{array}{c}\text { Decoalescing } \\
\text { signals }\end{array}$ & $\mathrm{T}_{\mathrm{c}}, \mathrm{K}$ & $\Delta v_{\mathrm{c}}, \mathrm{Hz}$ & $\mathrm{k}_{\mathrm{c}}, \mathrm{s}^{-1}$ & $\Delta \mathrm{G}_{\mathrm{c}}{ }^{\neq}, \mathrm{kcal} \mathrm{mol}^{-1}$ \\
\hline${ }^{1} \mathrm{H}(\mathrm{SiMe})$ & 195 & 160 & 355 & 9.0 \\
${ }^{13} \mathrm{C}(\mathrm{SiMe})$ & 203 & 500 & 1111 & 8.9 \\
${ }^{13} \mathrm{C}(\mathrm{C}-2)$ & 188 & 61 & 135 & 9.0 \\
${ }^{13} \mathrm{C}(\mathrm{C}-4)$ & 188 & 74 & 164 & 8.9 \\
${ }^{13} \mathrm{C}(\mathrm{C}-5)$ & 186 & 35 & 78 & 9.1 \\
& & & Mean & $\mathbf{9 . 0}$ \\
\hline
\end{tabular}

The mean value of the barrier is practically the same as that for the recently studied close analog of 1, 1,3,3-trimethyl-1,3-azasilinane $\left(9.1 \mathrm{kcal} \mathrm{mol}^{-1}\right){ }^{18}$ The measured barrier is lower than those in N-methylpiperidine $\left(14.4 \mathrm{kcal} \mathrm{mol}^{-1}\right)^{19}$ or 1,3,3-trimethylpiperidine $\left(10.8 \mathrm{kcal} \mathrm{mol}^{-1}\right){ }^{20}$ but markedly higher than that in 1-methyl-1-phenylsilacyclohexane $\left(5.5-6.0 \mathrm{kcal} \mathrm{mol}^{-1}\right) .^{14}$

In order to verify the conclusions about structure and participation of the predominant conformers in the conformational equilibrium made on the basis of the NMR criteria (vide supra), we have performed quantum chemical calculations of conformers $\mathbf{1 a}$ and $\mathbf{1 b}$ as well as their $\mathrm{NMe}_{\mathrm{ax}}$ counterparts at the MP2/6-311G(d,p) level of theory. The $\mathrm{Me}_{\mathrm{eq}} \mathrm{Ph}_{\mathrm{ax}}$ conformer 1a turned out to be $1.42 \mathrm{kcal} \mathrm{mol}^{-1}$ more stable than $\mathbf{1 b}$. The gas phase free energy difference $\Delta \mathrm{G}^{\mathrm{O}}(298 \mathrm{~K})=\Delta \mathrm{G}^{\mathrm{O}}(\mathbf{1} \mathbf{a})-\Delta \mathrm{G}^{\mathrm{O}}(\mathbf{1} \mathbf{b})$ obtained from vibrational calculations at the same level of theory is twice as low as that and equal to $0.74 \mathrm{kcal} \mathrm{mol}^{-1}$. This result is opposite to the unequivocal experimental result obtained in freon mixture, which may be attributed to additional stabilization of $\mathbf{1 b}$ in solution due to more accessible lone pair of the nitrogen atom in it (Fig. 4). Inclusion of PCM has changed slightly the calculated values but has not affected the trend discussed. Still, both the calculated and experimental values of $\Delta G^{\circ}$ are small, which is consistent with comparable amounts of the two conformers.

The corresponding $\mathrm{NMe}_{\mathrm{ax}}$ conformers are 5.23 and $4.97 \mathrm{kcal} \mathrm{mol}^{-1}$ higher in energy than 1a and $\mathbf{1 b}$, respectively, approving the presence of only one conformer for the given configuration of the substituents at silicon.

\section{Conclusions}

1,3-Dimethyl-3-phenyl-1,3-azasilinane $\mathbf{1}$ exists as an equilibrium mixture of the two conformers with equatorial $\mathrm{N}-\mathrm{Me}$ substitution and differing by the configuration of the phenyl and methyl substituents at the silicon atom, the $\mathrm{Ph}_{\mathrm{eq}} \mathrm{Me}_{\mathrm{ax}}$ conformer $\mathbf{1 b}$ being preferable. The ratio of the conformers $\mathrm{Ph}_{\mathrm{ax}} \mathrm{Me}_{\mathrm{eq}}: \mathrm{Ph}_{\mathrm{eq}} \mathrm{Me}_{\mathrm{ax}}$ is $1: 2$, and the barrier to the silapiperidine ring inversion calculated from decoalescence of five pairs of the ${ }^{1} \mathrm{H}$ and ${ }^{13} \mathrm{C}$ signals is $9.0 \mathrm{kcal} \mathrm{mol}^{-1}$, which 
practically coincides with the barrier in its close analog 1,3,3-trimethyl-1,3-azasilinane $(9.1 \mathrm{kcal}$ $\left.\mathrm{mol}^{-1}\right)$.

\section{Experimental Section}

General. Solvents were freshly distilled from the appropriate drying agents immediately before use (diethyl ether, sodium benzophenone ketyl; benzene, $\mathrm{CaH}_{2}$ ). The ${ }^{1} \mathrm{H},{ }^{13} \mathrm{C}$, and ${ }^{29} \mathrm{Si} \mathrm{NMR}$ spectra were recorded on a Brucker DPX 400 spectrometer $\left({ }^{1} \mathrm{H}, 400.1 \mathrm{MHz} ;{ }^{13} \mathrm{C}, 100.6 \mathrm{MHz}\right.$; $\left.{ }^{29} \mathrm{Si}, 79.5 \mathrm{MHz}\right)$. Chemical shifts (ppm) were determined relative to residual $\mathrm{CHCl}_{3}\left({ }^{1} \mathrm{H}, \delta 7.27\right.$, $\left.\mathrm{CDCl}_{3}\right)$, internal $\mathrm{CDCl}_{3}\left({ }^{13} \mathrm{C}, \delta 77.0, \mathrm{CDCl}_{3}\right)$, and external TMS $\left({ }^{29} \mathrm{Si}, \delta 0.00, \mathrm{CDCl}_{3}\right)$. The assignment of the ${ }^{1} \mathrm{H}$ and ${ }^{13} \mathrm{C}$ signals was made from the $j$-mod and $2 \mathrm{D}\left\{{ }^{1} \mathrm{H}-{ }^{13} \mathrm{C}\right\}$ NMR spectra at $298 \mathrm{~K}$ and $173 \mathrm{~K}$.

Low-temperature ${ }^{1} \mathrm{H}$ and ${ }^{13} \mathrm{C}$ NMR spectra were recorded on a Bruker AV-600 (at 600 and 150 $\mathrm{MHz}$, respectively). Chemical shifts were determined relative to residual internal $\mathrm{CD}_{2} \mathrm{Cl}_{2}\left({ }^{13} \mathrm{C}, \delta\right.$ 53.73) and are given in ppm downfield to TMS. Analysis and assignment of the ${ }^{1} \mathrm{H}$ NMR data were supported by homonuclear (COSY) and heteronuclear (HSQC $\left.{ }^{13} \mathrm{C}-{ }^{1} \mathrm{H}, \mathrm{HMBC}{ }^{13} \mathrm{C}-{ }^{1} \mathrm{H}\right) 2 \mathrm{D}$ correlation experiments. A solvent mixture of $\mathrm{CD}_{2} \mathrm{Cl}_{2}, \mathrm{CHFCl}_{2}$, and $\mathrm{CHF}_{2} \mathrm{Cl}$ in a ratio of 1:1:3 was used for the low temperature measurements. The probe temperature was calibrated by means of a thermocouple PT 100 inserted into a dummy tube. The low temperature measurements were estimated to be accurate to $\pm 2 \mathrm{~K}$. The chemical shifts difference $\Delta \mathrm{v}_{\mathrm{c}}, \mathrm{Hz}$ was determined by extrapolation from the lowest temperatures available to $\mathrm{T}_{\mathrm{c}}$ used to calculate $\mathrm{k}_{\mathrm{c}}$ and the ring inversion barriers by the Eyring equation at $\mathrm{T}_{\mathrm{c}}$.

The HRMS ESI spectra were recorded using a Micromass Q-TOF micro mass spectrometer in positive electrospray mode. All samples were injected $(10 \mu \mathrm{L} / \mathrm{min})$ with a Harvard syringe pump. The capillary voltage was set to $3.7 \mathrm{kV}$, with a cone voltage between 20-25 V. Elemental compositions were determined by accurate mass measurement with standard deviation $<5 \mathrm{ppm}$. $\mathrm{H}_{3} \mathrm{PO}_{4}$ was used as reference compound.

\section{Synthetic procedures}

(Chloromethyl)methyldichlorosilane (2) was commercially available. (Chloromethyl)methylphenylchlorosilane (3) and (chloromethyl)methylphenylsilane (4) were prepared following described procedures. ${ }^{12,21}$

NMR data for compound 4. ${ }^{1} \mathrm{H} \mathrm{NMR}\left(\mathrm{CDCl}_{3}\right): \delta_{\mathrm{H}} 0.53\left(3 \mathrm{H}, \mathrm{d}, J_{\mathrm{HH}}=3.7 \mathrm{~Hz}, \mathrm{MeSi}\right), 3.03(1 \mathrm{H}$, $\left.\mathrm{dd}, J_{\mathrm{HH}}=13.7,3.4 \mathrm{~Hz}, \mathrm{SiCH}{ }^{\mathrm{A}} \mathrm{Cl}\right), 3.09\left(1 \mathrm{H}, \mathrm{dd}, J_{\mathrm{HH}}=13.7,2.2 \mathrm{~Hz}, \mathrm{SiCH}^{\mathrm{B}} \mathrm{Cl}\right), 4.58(1 \mathrm{H}$, quint, $\left.\mathrm{d}, J_{\mathrm{HH}}=3.6,2.3 \mathrm{~Hz}, \mathrm{SiH}\right), 7.42\left(3 \mathrm{H}, \mathrm{m}, \mathrm{H}_{m+p}\right), 7.61\left(2 \mathrm{H}, \mathrm{m}, \mathrm{H}_{o}\right) .{ }^{13} \mathrm{C} \mathrm{NMR}\left(\mathrm{CDCl}_{3}\right): \delta_{\mathrm{C}}-7.12$ $(\mathrm{MeSi}), 28.12\left(\mathrm{SiCH}_{2} \mathrm{Cl}\right), 128.14\left(C_{m}\right), 130.17\left(C_{p}\right), 133.26\left(C_{o}\right), 134.55\left(C_{i}\right) .{ }^{29} \mathrm{Si} \mathrm{NMR}\left(\mathrm{CDCl}_{3}\right)$ : $\delta_{\mathrm{Si}}-14.86$.

Methylphenyl(chloromethyl)(3-chloropropyl)silane (5) was prepared from 4 and allyl chloride in the presence of $\mathrm{H}_{2} \mathrm{PtCl}_{6} \cdot 6 \mathrm{H}_{2} \mathrm{O}(0.1 \mathrm{~N}$ solution in $i$-PrOH $)$ by the known procedure ${ }^{22}$ in $11 \%$ 
yield and purified by column chromatography on silica gel (eluent $-n$-pentane). ${ }^{1} \mathrm{H}$ NMR $\left(\mathrm{CDCl}_{3}\right): \delta_{\mathrm{H}} 0.46(3 \mathrm{H}, \mathrm{s}, \mathrm{MeSi}), 1.08\left(1 \mathrm{H}, \mathrm{dd}, J_{\mathrm{HH}}=11.2,0.9 \mathrm{~Hz}, \operatorname{SiCH} H^{\mathrm{A} C}\right), 1.10\left(1 \mathrm{H}, \mathrm{d}, J_{\mathrm{HH}}=\right.$ $\left.11.2 \mathrm{~Hz}, \mathrm{SiCH}{ }^{\mathrm{B}} \mathrm{CC}\right), 1.87\left(2 \mathrm{H}, \mathrm{m}, \mathrm{SiCCH}_{2} \mathrm{C}\right), 3.01\left(1 \mathrm{H}, \mathrm{d}, J_{\mathrm{HH}}=13.8 \mathrm{~Hz}, \mathrm{SiCH}{ }^{\mathrm{A}} \mathrm{Cl}\right), 3.06(1 \mathrm{H}$, $\left.\mathrm{d}, J_{\mathrm{HH}}=13.8 \mathrm{~Hz}, \mathrm{SiCH}{ }^{\mathrm{B}} \mathrm{Cl}\right), 3.54\left(2 \mathrm{H}, \mathrm{t}, J_{\mathrm{HH}}=6.8 \mathrm{~Hz}, \mathrm{CCH}_{2} \mathrm{Cl}\right) 7.43\left(3 \mathrm{H}, \mathrm{m}, \mathrm{H}_{m+p}\right), 7.56(2 \mathrm{H}$, $\left.\mathrm{m}, \mathrm{H}_{o}\right) .{ }^{13} \mathrm{C} \mathrm{NMR}\left(\mathrm{CDCl}_{3}\right): \delta_{\mathrm{C}}-6.31\left(\mathrm{SiCH}_{3}\right), 10.29\left(\mathrm{SiCH}_{2} \mathrm{C}\right), 27.16\left(\mathrm{CCH}_{2} \mathrm{C}\right), 28.98$ $\left(\mathrm{SiCH}_{2} \mathrm{Cl}\right), 47.65\left(\mathrm{CCH}_{2} \mathrm{Cl}\right), 128.15\left(C_{m}\right), 129.95\left(C_{p}\right), 133.93\left(C_{o}\right), 134.60\left(C_{i}\right) .{ }^{29} \mathrm{Si} \mathrm{NMR}$ $\left(\mathrm{CDCl}_{3}\right): \delta_{\mathrm{Si}}-2.65$.

1,3-Dimethyl-3-phenyl-1,3-azasilinane (1). A mixture of methylphenyl(chloromethyl)(3chloropropyl)silane 5 (5.449 g, $22 \mathrm{mmol})$, methylamine $(2.469 \mathrm{~g}, 79 \mathrm{mmol})$ and benzene $(20 \mathrm{ml})$ was heated in a sealed ampoule for $6 \mathrm{~h}$ at $160{ }^{\circ} \mathrm{C}$. The precipitate formed was filtered off and washed with benzene. Volatile components of the organic phase were removed under reduced pressure and the oily residue was purifed by column chromatography on silica gel using dichloromethane/methanol $(9: 1, \mathrm{v} / \mathrm{v})$ as the eluent. The relevant fractions were combined and the solvents removed under reduced pressure to give $\mathbf{1}$ in $58 \%$ yield as a colorless viscous liquid. ${ }^{1} \mathrm{H}$ and ${ }^{13} \mathrm{C}$ NMR data are given in Table $1 .{ }^{29} \mathrm{Si} \mathrm{NMR}\left(\mathrm{CDCl}_{3}\right): \delta_{\mathrm{Si}}-12.53$. HRMS (ESI): $[\mathrm{M}+\mathrm{H}]^{+}$, found 206.1347. $\mathrm{C}_{12} \mathrm{H}_{20} \mathrm{NSi}$ requires 206.1365.

\section{Theoretical calculations}

Optimization of geometry and vibrational calculations were performed at the MP2 level of theory with the 6-311G(d,p) basis set. Unscaled ZPE corrections were used. All calculations were performed with the Gaussian 09 computational program. ${ }^{23}$ No restrictions on the variation of geometric parameters were imposed during the optimization procedure. For $\mathbf{1 a}$ and $\mathbf{1 b}$ the calculated MP2/6-311G(d,p) energies are -811.0102473 au and -811.0079776 au, respectively; $\Delta \mathrm{E}$ is $1.42 \mathrm{kcal} \mathrm{mol}^{-1}$ and $\Delta \mathrm{G}^{\circ}(298 \mathrm{~K})$ proves to be $0.74 \mathrm{kcal} \mathrm{mol}^{-1}$ (from vibrational calculations) in the gas phase. The solvent in $\mathrm{PCM}$ calculations was $\mathrm{CHCl}_{3}$ (maximally close to the NMR experiment). PCM calculations were performed with full geometry optimization and changed $\Delta \mathrm{G}^{\circ}(298 \mathrm{~K})$ only negligibly to $0.79 \mathrm{kcal} \mathrm{mol}^{-1}$ compared with the gas phase value.

\section{Acknowledgements}

The financial support of this work by the Russian Foundation for Basic Research and Deutsche Forschungsgemeinschaft (Grant RFBR-DFG No. 11-03-91334) is greatly acknowledged. We thank Dipl.-Ing (FA) Angela Krtitschka and Dr. Matthias Heydenreich (University of Potsdam) for preparing the freon sample and recording the low-temperature NMR spectra and Dipl.-Ing (FA) Sylvia Fürstenberg for the high resolution mass spectrum.

\section{References}

1. Rousseau, G.; Blanco, L. Tetrahedron 2006, 62, 7951, and references therein.

2. Meanwell, N. A. J. Med. Chem. 2011, 54, 2529. 
3. Gerlach, M.; Jutzi, P.; Stasch. J. P.; Przuntek, H. Z. Naturforsch. 1982, B37, 657.

4. Stasch, J.-P.; Ruß, H.; Schacht, U.; Witteler, M.; Neuser, D.; Gerlach, M.; Leven, M.; Kuhn, W.; Jutzi, P.; Przuntek, H. Arzneim.-Forsch./Drug Res. 1988, 38(II), 1075.

5. Tacke, R.; Heinrich, T.; Bertermann, R.; Burschka, C.; Hamacher, A.; Kassack, M. U. Organometallics 2004, 23, 4468.

6. Heinrich, T.; Burschka, C.; Penka, M.; Wagner, B.; Tacke, R. J. Organometal. Chem. 2005, $690,33$.

7. Ilg, R.; Burschka, C.; Schepmann, D.; Wünsch, B.; Tacke, R. Organometallics 2006, 25, 5396.

8. Tacke, R.; Nguyen, B.; Burschka, C.; Lippert, W. P.; Hamacher, A.; Urban, C.; Kassack, M. U. Organometallics 2010, 29, 1652.

9. Blaszykowski, C.; Brancour, C.; Dhimane, A.-L.; Fensterbank, L.; Malacria, M. Eur. J. Org. Chem. 2009, 1674.

10. Hernández, D.; Nielsen, L., Lindsay, K. B.; López-García, M. Á.; Bjerglund, K.; Skrydstrup, T. Org. Lett. 2010, 12, 3528.

11. Casy, A. F.; Iorio, M. A.; Madani, A. E. Org. Magn. Res. 1987, 25, 524.

12. Kirpichenko, S. V.; Albanov, A. I. J. Organometal. Chem. 2010, 695, 663.

13. Kirpichenko, S. V.; Kleinpeter, E.; Ushakov, I.; Shainyan, B.A. J. Phys. Org. Chem. 2011, 24, 320.

14. Shainyan, B. A.; Kleinpeter, E. Tetrahedron 2012, 68, 114.

15. Bushweller, C. H. In: Conformational Behavior of Six-Membered Rings. Analysis, Dynamics, and Stereoelectronic Effects (Ed. E. Juaristi) Wiley-VCH: New York, 1995, 25.

16. Eliel, E. L.; Manoharan, M. J. Org. Chem., 1981, 46, 1959.

17. Wiberg, K. B.; Castejon, H.; Bailey, W. F.; Ochterski, J. J. Org. Chem. 2000, 65, 1181.

18. Shainyan, B. A.; Kirpichenko, S. V.; Shlykov, S.; Kleinpeter, E. J. Phys. Chem. A 2012, 116, 784.

19. Lambert, J. B.; Keske, R. G.; Carhart, R. E.; Jovanovich, A. P. J. Am. Chem. Soc. 1967, 89, 3761.

20. Lambert, J. B.; Keske, R. G. J. Am. Chem. Soc. 1966, 88, 620.

21. Allen, J. M.; Aprahamian, S.L.; Sans, E.A.; Shechter, H. J. Org. Chem. 2002, 67, 3561.

22. Belyakova, Z. V.; Pomerantseva, M. G.; Golubtsov, S. A. Zh. Obshch. Khim. 1965, 35, 1048.

23. Frisch, M. J.; Trucks, G. W.; Schlegel, H. B.; Scuseria, G. E.; Robb, M. A.; Cheeseman, J. R.; Scalmani, G.; Barone, V.; Mennucci, B.; Petersson, G. A.; Nakatsuji, H.; Caricato, M.; Li, X.; Hratchian, H. P.; Izmaylov, A. F.; Bloino, J.; Zheng, G.; Sonnenberg, J. L.; Hada, M.; Ehara, M.; Toyota, K.; Fukuda, R.; Hasegawa, J.; Ishida, M.; Nakajima, T.; Honda, Y.; Kitao, O.; Nakai, H.; Vreven, T.; Montgomery, J. A., Jr.; Peralta, J. E.; Ogliaro, F.; Bearpark, M.; Heyd, J. J.; Brothers, E.; Kudin, K. N.; Staroverov, V. N.; Kobayashi, R.; Normand, J.; Raghavachari, K.; Rendell, A.; Burant, J. C.; Iyengar, S. S.; Tomasi, J.; Cossi, M.; Rega, N.; Millam, J. M.; Klene, M.; Knox, J. E.; Cross, J. B.; Bakken, V.; Adamo, C.; Jaramillo, J.; Gomperts, R.; Stratmann, R. E.; Yazyev, O.; Austin, A. J.; Cammi, R.; Pomelli, C.; 
Ochterski, J. W.; Martin, R. L.; Morokuma, K.; Zakrzewski, V. G.; Voth, G. A.; Salvador, P.; Dannenberg, J. J.; Dapprich, S.; Daniels, A. D.; Farkas, O.; Foresman, J. B.; Ortiz, J. V.; Cioslowski, J.; Fox, D. J. Gaussian, Inc., Wallingford CT, 2009. 